\title{
Protein Expression upon Desiccation and Imbibition of Magnolia ovata A. St.-Hil seeds
}

\author{
Anderson Cleiton José ${ }^{*}$, Edvaldo Aparecido Amaral da Silva ${ }^{2}$, Antonio Claudio Davide ${ }^{1}$ \\ and Peter Toorop ${ }^{3}$ \\ ${ }^{I}$ Departamento de Ciências Florestais; Universidade Federal de Lavras; C.P.: 3037; 37200-000; Lavras - MG - \\ Brasil. ${ }^{2}$ Fazenda Experimental Lageado; Faculdade de Ciências Agronômicas de Botucatu; Universidade Estadual \\ Paulista Júlio de Mesquita Filho; 18603-970; Botucatu - SP - Brasil. ${ }^{3}$ Seed Conservation Department-Royal \\ Botanic Gardens; H17 6TN; Wakehurst Place-Ardingly; West Sussex - United Kingdom
}

\begin{abstract}
The effect of seed drying and imbibition was studied by differential protein expression using two dimensional gel electrophoresis. After drying to a range of water contents, seeds were germinated to assess the viability. Seeds of Magnolia ovata did not withstand the desiccation down to $0.10 \mathrm{~g} \mathrm{H}_{2} \mathrm{O} \cdot \mathrm{g}^{-1} \mathrm{dw}$. The critical water content below which the desiccation sensitivity became apparent was around $0.18 \mathrm{~g} \mathrm{H}_{2} \mathrm{O} \cdot \mathrm{g}^{-1} \mathrm{dw}(-26.5 \mathrm{MPa})$. Total protein was extracted and separated by $2 \mathrm{D}$ electrophoresis from fresh seeds $\left(0.28 \mathrm{~g} \mathrm{H} \mathrm{H}_{2} \cdot \mathrm{g}^{-1} \mathrm{dw}\right)$, mild dried seeds $\left(0.25 \mathrm{~g} \mathrm{H}_{2} \mathrm{O}\right.$. $\left.g^{-1} d w\right)$ and seeds at low water content $\left(0.10 \mathrm{~g} \mathrm{H}_{2} \mathrm{O} \cdot \mathrm{g}^{-1} \mathrm{dw}\right)$ before and after imbibition for 10 days. The proteome profile revealed the presence of 588 spots on each silver stained gel, from which 21 showed differential expression, correlated with desiccation and germination, by increased or decreased expression. After MS/MS sequencing, three protein spots produced spectra that matched to a Magnolia salicifolia legumin precursor. Results suggested an involvement of this protein in the events taking place during the drying and subsequent imbibitions of the dried seeds.
\end{abstract}

Key words: desiccation tolerance, forest seed, legumin, proteomics

\section{INTRODUCTION}

Magnolia ovata A. St.-Hil is a tree widely distributed in the Brazilian Atlantic Forest, ranging from north (Para State) to south (Rio Grande do Sul State). It is widespread in different vegetation types like rainforest, semideciduous forest and Cerrado (Brazilian savannah). However, its occurrence is particularly related to wet soils of riparian forests, a susceptible environment in various Brazilian ecosystems. This species is used for restoration of riparian forests due to its adaptation to swampy soils. $M$. ovata has also been used in folk medicine as a febrifuge (Pio-Corrêa, 1984) and anti-diabetes (Morato et al., 1988) in some parts of Brazil.

Seeds from most species desiccate at the end of maturation, but not all the seeds survive the desiccation.

Desiccation tolerance is a complex multigenic trait (Leprince et al., 1993; Vertucci and Farrant, 1995). It is the result of a complex cascade of molecular events, which can be divided into signal perception, signal transduction, gene activation

*Author for correspondence: acjose@ dcf.ufla.br 
and biochemical changes leading to the acquisition of desiccation tolerance (Bartels and Salamini, 2001; Ramanjalu and Bartels, 2002). Desiccation tolerance is characterized by the physical and chemical adjustments in order for the cells to withstand the dehydration and resume the biological activity after rehydration. Some of these mechanisms include a reduction in the degree of vacuolation, changes in the amount and nature of accumulated insoluble reserves, conformation of the DNA, chromatin and nuclear architecture, intracellular de-differentiation, "switching off" of metabolism, activation of antioxidant systems, accumulation of putatively protective molecules such as proteins (LEAs) and sugars, positioning of amphipathic molecules, protection of oil bodies by oleosins, and the presence of repair mechanisms during the rehydration (Pammenter and Berjak, 1999).

Combined studies of seed physiology and molecular genetics have provided good insights into regulatory networks involved in the development and germination of the seeds (Koornneef et al., 2002). Proteomics is one of the most important developments used for seed physiology studies in recent years (Bove et al., 2001; van der Geest, 2002; Bertone and Snyder, 2005). This study describes the identification of proteins that are differentially expressed during desiccation and germination of $M$. ovata seeds.

\section{MATERIAL AND METHODS}

Magnolia ovata fruits were collected from 12 trees along the Rio Grande river near Lavras (MG, Brazil) in September 2004. After collection, the fruits were left at room temperature to allow the completion of dehiscence, which occurred between 3 to 4 days. Seeds were removed, counted and average seed number with standard deviation per fruit was calculated. The red aril that covered the seed was removed by gentle rubbing on a mesh and rinsing with tap water. After cleaning, the seeds were blotted dry with a paper towel to remove the excess water, and seeds were stored at $5^{\circ} \mathrm{C}$ in closed plastic bags. Seeds were used within two months of harvest.

\section{Desiccation conditions}

Desiccation was carried out over a saturated $90 \%$ $(\mathrm{w} / \mathrm{v})$ lithium chloride solution, providing a relative humidity of $11 \%$ at $20^{\circ} \mathrm{C}$ (Sun 2002).
Estimated water content was monitored each hour by the difference between the initial weight of fresh and dried seeds. When seeds reached the estimated target water content, three samples were taken: one sample of 20 seeds for water content determination, one sample of 100 seeds for germination and one sample of 25 seeds for total protein extraction. The latter seeds were frozen in liquid nitrogen and stored at $-70^{\circ} \mathrm{C}$ until processing.

\section{Water content, water potential and oil content assessment}

The water content of the whole seed was determined gravimetrically on four replications of five seeds by oven drying at $103^{\circ} \mathrm{C}$ for $17 \mathrm{~h}$ (ISTA, 2005) and expressed as $\mathrm{g}_{2} \mathrm{O} \cdot \mathrm{g}$ dry weight $^{-1}$, or $\mathrm{g} \mathrm{H}_{2} \mathrm{O} \cdot \mathrm{g}^{-1} \mathrm{dw}$.For water potential measurements, a desorption isotherm using a range of lithium chloride solutions providing different relative humidity was established. Equilibrium relative humidity $(\mathrm{eRH})$ of whole seeds was measured with a Rotronic Hygrometer (Probert et al., 2002) in four replicates of 25 seeds over 60 minutes. The water potential $\left(\Psi_{\mathrm{w}}\right)$ was calculated from eRH using the equation $\left(\Psi_{\mathrm{w}}\right)=(\mathrm{RT} / \mathrm{V}) \cdot \mathrm{ln}$ $\left(\mathrm{a}_{\mathrm{w}}\right)$, where $R$ is the gas constant $\left(8.314 \mathrm{~J} \mathrm{~mol}^{-1} \mathrm{~K}^{-}\right.$ ${ }^{1}$ ), $T$ is the temperature (Kelvin), $V$ is the partial molal volume of water $\left(18.048 \mathrm{ml} \mathrm{mole}^{-1}\right)$ and $\mathrm{a}_{\mathrm{w}}$ is the water activity (eRH/100) (Sun, 2002).

The seed oil content was estimated using the supercritical fluid extraction method (Eller and King, 2000). An SFX 3560 (ISCO USA) was used with the following extraction conditions: pressure $7500 \mathrm{psi}$; temperature $100^{\circ} \mathrm{C}$; time $30 \mathrm{~min}$; flow rate $2 \mathrm{ml} \mathrm{min}{ }^{-1}$.

\section{Seed germination and viability assessment}

Immediately after the desiccation, the seeds were soaked on moist filter paper (filter paper 595, Ø 85 $\mathrm{mm}$, Schleicher and Schuell, Dassel, Germany) in $9 \mathrm{~cm}$ Petri dishes for $24 \mathrm{~h}$ with $5 \mathrm{ml}$ distilled water. Subsequently, seeds were cleaned with $1 \%$ sodium hypochlorite for 10 minutes and rinsed with distilled water. Germination assays were carried out with four replicates of 25 seeds. Seeds were incubated at alternating temperature $20^{\circ} \mathrm{C} / 10^{\circ} \mathrm{C}$ (day/night), with $8 \mathrm{~h}$ light daily on two sheets of filter paper Schleicher and Schuell 595 wetted with $5 \mathrm{ml}$ of distilled water in disposable $9 \mathrm{~cm}$ Petri dishes. A seed was regarded as germinated when the radicle protruded $2 \mathrm{~mm}$ through the seed coat. After 10 days of imbibition, 
a sample of 25 seeds was taken for protein extraction. These seeds were frozen in liquid nitrogen and stored at $-70^{\circ} \mathrm{C}$.

Germination tests were carried out for 80 days. Non-germinated seeds after this period were evaluated by a cut test in order to assess the viability of the seeds. Seeds were regarded as dead if mushy, liquid or rotten endosperm was present. On the other hand, if a firm and white endosperm and embryo were present, seeds were scored as viable (Gosling, 2002; ISTA, 2005) and reported as "dormant" seeds. To confirm the applicability of the cut test, a tetrazolium test was performed using the same conditions, which showed the same results (data not shown), similar to results reported for Leucopogon species (Ooi and Whelan, 2004).

\section{Total protein extraction}

Total protein extracts were prepared from the seeds dried at different water contents and from the seeds subsequently imbibed for 10 days. Three samples of five seeds each were ground in liquid nitrogen using a mortar and pestle. Total protein was extracted according to Gallardo et al (2003), with small modifications. Briefly, after ground, the powder was homogenized on ice with $800 \mu \mathrm{L}$ of thiourea, urea lysis buffer containing $7 \mathrm{M}$ urea, $2 \mathrm{M}$ thiourea, $18 \mathrm{mM}$ Trizma $\mathrm{HCl}, 14 \mathrm{mM}$ Trizma base, protease inhibitor cocktail Complete Mini (Roche Diagnostics), 12 units DNAse I, 20 $\mu$ L RNAse A (20mg/mL), $0.2 \%$ (v/v) Triton X-100, 60mM CHAPS and $17.5 \mathrm{mM}$ DTT. After 20 minutes, the tubes were centrifuged at $14,000 \mathrm{rpm}$ for 10 minutes at $4^{\circ} \mathrm{C}$. The supernatant containing the total protein extract was submitted to a second clarifying centrifugation as above and supernatant was stored at $-20^{\circ} \mathrm{C}$ in aliquots of $100 \mu \mathrm{L}$.

Protein concentration in the various extracts was measured according to Bradford (1976), using bovine serum albumin (BSA) as a standard.

\section{Two-dimensional electrophoresis}

Proteins were separated by isoelectric focusing (IEF) using $24 \mathrm{~cm}$ Immobiline DryStrips with a nonlinear $\mathrm{pH}$ gradient from 3 to 10 (Amersham Biosciences). Gel strips were rehydrated in the IPGphor system (Amersham Biosciences) for $14 \mathrm{~h}$ at $20^{\circ} \mathrm{C}$ in the thiourea/urea buffer containing $2 \mathrm{M}$ thiourea, 7M urea, $1.2 \%$ (v/v) DeStreak Reagent (Amersham Biosciences), 2\% CHAPS (w/v) and $0.5 \%$ IPG buffer $\mathrm{pH} 3$ to 10 according to manufacturer instructions. A final volume of 450 $\mu \mathrm{L}$ of solution was applied to each strip holder.
After positioning the gel strip in the strip holder, $1.9 \mathrm{ml}$ of cover solution (Amersham Biosciences) was applied and the strip holder lid was replaced. Isoelectric focusing was then performed at $20^{\circ} \mathrm{C}$ at $500 \mathrm{~V}$ for $1 \mathrm{~h}, 1000 \mathrm{~V}$ for $1 \mathrm{~h}, 8000 \mathrm{~V}$ for $8 \mathrm{~h}$ and 20 minutes and $50 \mathrm{~V}$ for up to $1 \mathrm{~h}$. Gel strips were stored at $-70^{\circ} \mathrm{C}$ in equilibration tubes until second dimension electrophoresis. Before second dimension electrophoresis, the gel strips were equilibrated in $15 \mathrm{ml}$ equilibration solution containing $6 \mathrm{M}$ urea, $30 \%$ (v/v) glycerol, $2 \%(\mathrm{w} / \mathrm{v})$ SDS, $75 \mathrm{mM}$ Trizma base $\mathrm{pH} 8.8$, with $65 \mathrm{mM}$ DTT $\left(1^{\text {st }}\right.$ step $)$, without addition $\left(2^{\text {nd }}\right.$ step $)$ and with $0.2 \mathrm{M}$ iodoacetamide ( ${ }^{\text {rd }}$ step), $40 \mathrm{~min}$ per equilibration step. Equilibrated gel strips were placed on top of $1 \mathrm{~mm}$ vertical polyacrylamide gels containing $9.4 \%(\mathrm{v} / \mathrm{v})$ acrylamide, $70 \mathrm{mM}$ Bis(acryloyl) piperazine, $0.3 \mathrm{M}$ Trizma base $\mathrm{pH}$ $8.8,0.08 \%(\mathrm{w} / \mathrm{v})$ ammonium persulphate and $0.04 \%(\mathrm{v} / \mathrm{v})$ TEMED. Gel strips were sealed with $1 \%(\mathrm{w} / \mathrm{v})$ low-melting point agarose containing $0.2 \%(\mathrm{w} / \mathrm{v})$ SDS, $50 \mathrm{mM}$ Trizma base, $0.4 \mathrm{M}$ glycine and trace bromophenol blue. Gels were left for $5 \mathrm{~min}$ to allow agarose solidification. Electrophoresis was performed at $25^{\circ} \mathrm{C}$ in a buffer containing $0.1 \%(\mathrm{w} / \mathrm{v})$ SDS, $95 \mathrm{mM}$ glycine and $12.5 \mathrm{mM}$ Trizma base, for $1 \mathrm{~h}$ at $2.5 \mathrm{~V} / \mathrm{gel}$ and $4.5 \mathrm{~h}$ at $17 \mathrm{~V} / \mathrm{gel}$, in an Ettan DALTtwelve system (Amersham Biosciences), according to manufacturer instructions. For each condition, triplicate gels were electrophoresed using independent protein extracts.

\section{Protein staining and analysis of 2D gels}

Gels were stained with the PlusOne Silver Staining Kit (Amersham Biosciences), or Colloidal Coomassie Brilliant Blue G-250, according to manufacturer instructions. Stained gels were scanned with the ImageScanner (Amersham Biosciences), equipped with Ulmax MagiScan 4.6 in the transmissive mode with 300dpi. Image analysis was carried out with ImageMaster 2D Platinum 5.0 (Amersham Biosciences). After spot detection gels were aligned, matched and quantitative determination of the spot number and volumes was performed. When necessary, gels were normalized using a scatter plot fitting report method. Analysis of groups, classes and statistical tests (student's t-test) were then performed. Spots with a 2-fold difference and a significant result in the t-test $(\mathrm{P}<0.05)$ were regarded as differentially expressed. 


\section{Protein identification by MS/MS}

Protein spots with differential expression were manually excised from Coomassie Blue-Stained 2D gels using a sterile scalpel and digested by sequencing grade, modified porcine trypsin (Promega, Madison, WI). Samples were applied directly to the MALDI target plate and positiveion MALDI mass spectra were obtained using an Applied Biosystems 4700 Proteomics Analyzer (Applied Biosystems, Foster City, CA, USA) in reflectron mode. MS spectra were acquired over a mass range of $\mathrm{m} / \mathrm{z}$ 800-4000. Final mass spectra were internally calibrated using the tryptic autoproteolysis products at $\mathrm{m} / \mathrm{z} 842.509$ and 2211.104. Monoisotopic masses were obtained from centroids of raw, unsmoothed data. The twenty strongest peaks with a signal to noise greater than 50 were selected for CID-MS/MS analysis.

For CID-MS/MS, source 1 collision energy of 1 $\mathrm{kV}$ was used, with air as the collision gas. The precursor mass window was set to a relative resolution of 50, and the metastable suppressor was enabled. The default calibration was used for MS/MS spectra, which were baseline-subtracted (peak width 50) and smoothed (Savitsky-Golay with three points across a peak and polynomial order 4); peak detection used a minimum $\mathrm{S} / \mathrm{N}$ of 5 , local noise window of $50 \mathrm{~m} / \mathrm{z}$, and minimum peak width of 2.9 bins. Filters of S/N 20 and 30 were used for generating peak lists from MS and MS/MS spectra, respectively.

Mass spectral data obtained in batch mode were submitted to database search using a locallyrunning copy of the Mascot program (Matrix Science Ltd., version 1.9). Batch-acquired MS and MS/MS spectral data were submitted to a combined peptide mass fingerprint and MS/MS ion search through the Applied Biosystems GPS Explorer software interface (version 3.5) to Mascot. Search criteria included: Maximum missed cleavages, 1; Variable modifications, Oxidation (M), Carbamidomethyl; Peptide tolerance, $100 \mathrm{ppm}$; MS/MS tolerance, 0.1 Da.

\section{RESULTS AND DISCUSSION}

General characteristics of the fruits, seeds and effect of drying on the germination of $M$. ovata seeds

The fruits were greenish, ovoid in shape, dehiscent, and contained around $65( \pm 10)$ seeds each. The testa was black, covered by a red aril and remained attached to the fruit by a lignin-fibril after fruit opening. A woody testa covered the oily endosperm, of which the oil content was $32.7 \%$. The seeds contained a small embryo (approx. $1 \mathrm{~mm}$ long) with embryonic axis and differentiated cotyledons.Fresh seeds were exposed to a $\mathrm{RH}$ of $11 \%$ at $20^{\circ} \mathrm{C}$ for different periods of time. Seed water content decreased with progressing time and was observed an effect of the drying on germination and viability of $M$. ovata seeds (Fig 1).

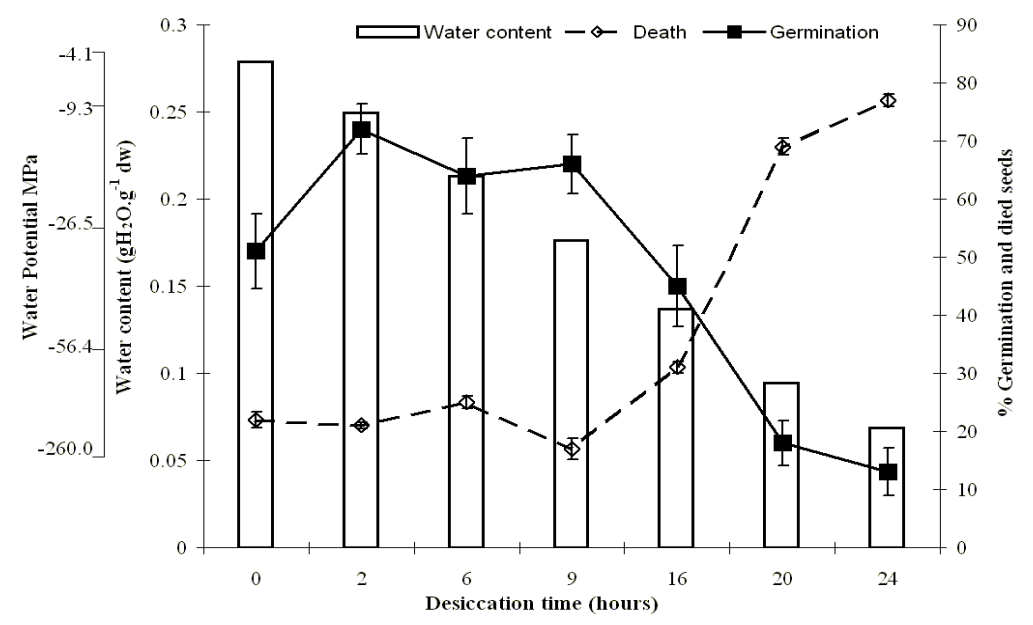

Figure 1 - Effect of drying on germination and viability of M. ovata. Final germination was scored after 80 days of incubation at $20 / 10^{\circ} \mathrm{C}$. An axis for water potential is presented for reference to water content. Error bars represent the standard error of the mean (when bigger than symbols). 
Desiccation damage, expressed as the reduction in the number of viable seeds was observed when the seeds were dried to water content below $0.18 \mathrm{~g} \mathrm{H}_{2} \mathrm{O}$ $\mathrm{g}^{-1} \mathrm{dw}$, which was equivalent to a water potential of $-26.5 \mathrm{MPa}$. Further drying resulted in an increase in the number of dead seeds and conversely a reduction in germination could be observed.

Germination was typically very slow, with radicle protrusion initiating 40 days after imbibition (results not shown). This was preceded by the start of seed coat rupture after 10 days of imbibition, which was indicative of seed viability since it was observed in the germinating and dormant seeds but not in dead seeds. After 80 days, the majority of seeds had either germinated or died. Seed germination was higher in the seeds dried to intermediate water contents $\left(0.25\right.$ to $0.18 \mathrm{~g} \mathrm{H}_{2} \mathrm{O}$. $\left.\mathrm{g}^{-1} \mathrm{dw}\right)$ than fresh seeds $\left(0.28 \mathrm{~g} \mathrm{H}_{2} \mathrm{O} \cdot \mathrm{g}^{-1} \mathrm{dw}\right)$. The number of dead seeds was relatively constant down to $0.18 \mathrm{~g} \mathrm{H}_{2} \mathrm{O} \cdot \mathrm{g}^{-1} \mathrm{dw}$ of water content. Beyond this point, dehydration caused an increase in the number of dead seed. It showed that the critical water potential (below which desiccation sensitivity became apparent) was around -26.5 MPa (0.18 g $\mathrm{H}_{2} \mathrm{O} \cdot \mathrm{g}^{-1} \mathrm{dw}$ ). However, at low water potential, some seeds were still viable. Although the vast majority of the seeds for all the different water contents had either germinated or died, a reasonable number of dormant seeds (27\%) was found after 80 days of imbibition of fresh seeds; this number was reduced to about $7 \%$ when the seeds were dried to $0.25 \mathrm{~g} \mathrm{H}_{2} \mathrm{O} \cdot \mathrm{g}^{-1} \mathrm{dw}$.

Recalcitrant seeds are those that cannot survive desiccation to low water contents, usually below $0.10 \mathrm{~g} \mathrm{H}_{2} \mathrm{O} \mathrm{g} \mathrm{g}^{-1} \mathrm{dw}$ (Roberts, 1973; Ellis et al., 1990; Hong et al., 1996). The loss of viability in $M$. ovata seeds occurred after drying to water contents below $0.18 \quad \mathrm{~g} \quad \mathrm{H}_{2} \mathrm{O} \quad \mathrm{g}^{-1} \mathrm{dw}$. This corresponded to a water potential of $-26.5 \mathrm{MPa}$, which was also close to the critical water potential of -23MPa found by Sun and Liang (2001) for Artocarpus heterophyllus and Hevea brasiliensis and -20MPa found by Pritchard (1991) for Quercus rubra, all desiccation sensitive species.

After mild drying, before reaching the critical water content, a slight increase in the germination was observed. This has been attributed to a continuation of the maturation process in recalcitrant seeds of Inga vera (Faria et al., 2004). This observation was inversely related to the fraction of dormant seeds, which was higher in the fresh seeds $\left(0.28 \mathrm{~g} \mathrm{H}_{2} \mathrm{O} \mathrm{g}^{-1} \mathrm{dw}\right)$ compared to mild dried seeds $\left(0.25 \mathrm{~g} \mathrm{H}_{2} \mathrm{O} \mathrm{g}^{-1} \mathrm{dw}\right)$. Further drying to
$0.10 \mathrm{~g} \mathrm{H}_{2} \mathrm{O} \mathrm{g}^{-1} \mathrm{dw}$ concurred with a larger fraction of dormant seeds again (data not shown). Changes in the dormancy in relation to the desiccation have been reported in papaya seeds, where dormancy was induced when seeds were dried (Wood et al., 2000).

Although $M$. ovata seeds were sensitive to desiccation, some seeds were still viable after drying to $0.07 \mathrm{~g} \mathrm{H}_{2} \mathrm{O} \mathrm{g}^{-1} \mathrm{dw}(-93 \mathrm{MPa})$. Many factors, such as the seed maturity, desiccation rate, imbibitional injury, chilling sensitivity, and dormancy, have been described to show an important role in storage behaviour. The manipulation of water content and germination of the seeds that experienced some of these factors might be rather complex. As an example, neem (Azadirachta indica) seeds are chilling sensitive at high water content and sensitive to imbibitional stress at low water contents (Sacandé, 2000).

\section{Proteome analysis: Effect of drying and drying/imbibition treatments on the patterns of protein expression in M. ovata seeds}

Based on the desiccation sensitivity and number of dormant seeds after 80 days of imbibition, three samples were selected for proteomics studies. Fresh seeds $\left(0.28 \mathrm{~g} \mathrm{H}_{2} \mathrm{O} \cdot \mathrm{g}^{-1} \mathrm{dw}\right)$ with high viability; mild dried seeds $\left(0.25 \mathrm{~g} \mathrm{H}_{2} \mathrm{O} \cdot \mathrm{g}^{-1} \mathrm{dw}\right)$ with reduced dormancy and high viability; and seeds at low water content $\left(0.10 \mathrm{~g} \mathrm{H}_{2} \mathrm{O} \cdot \mathrm{g}^{-1} \mathrm{dw}\right)$ with reduced viability. Although seeds dried to low water content presented low viability, they were not yet dead after 10 days of imbibition; thus, it was assumed that the protein patterns of these samples reflected the behaviour of dying seeds.

The proteome profile of $M$. ovata seeds revealed the presence of $588 \pm 69$ spots on each silver stained gel. After alignment, $61 \%$ of the spots were matched. A high experimental reproducibility was achieved. A characteristic result for $M$. ovata seeds was the presence of highly abundant proteins, which were most probably storage proteins. A large majority of the proteins were focussed between pI 5-8. Differential expression was found only for the proteins with a molecular mass between 15 and 50 $\mathrm{KDa}$. Comparing the silver stained gels from different conditions (different water content, before and after imbibition) enabled identification of up to 21 protein spots with differential expression (Fig.2). Of these, 13 could be identified in Coomassie-stained gels for manual spot picking, in-gel digestion and peptide mass spectrometry. 


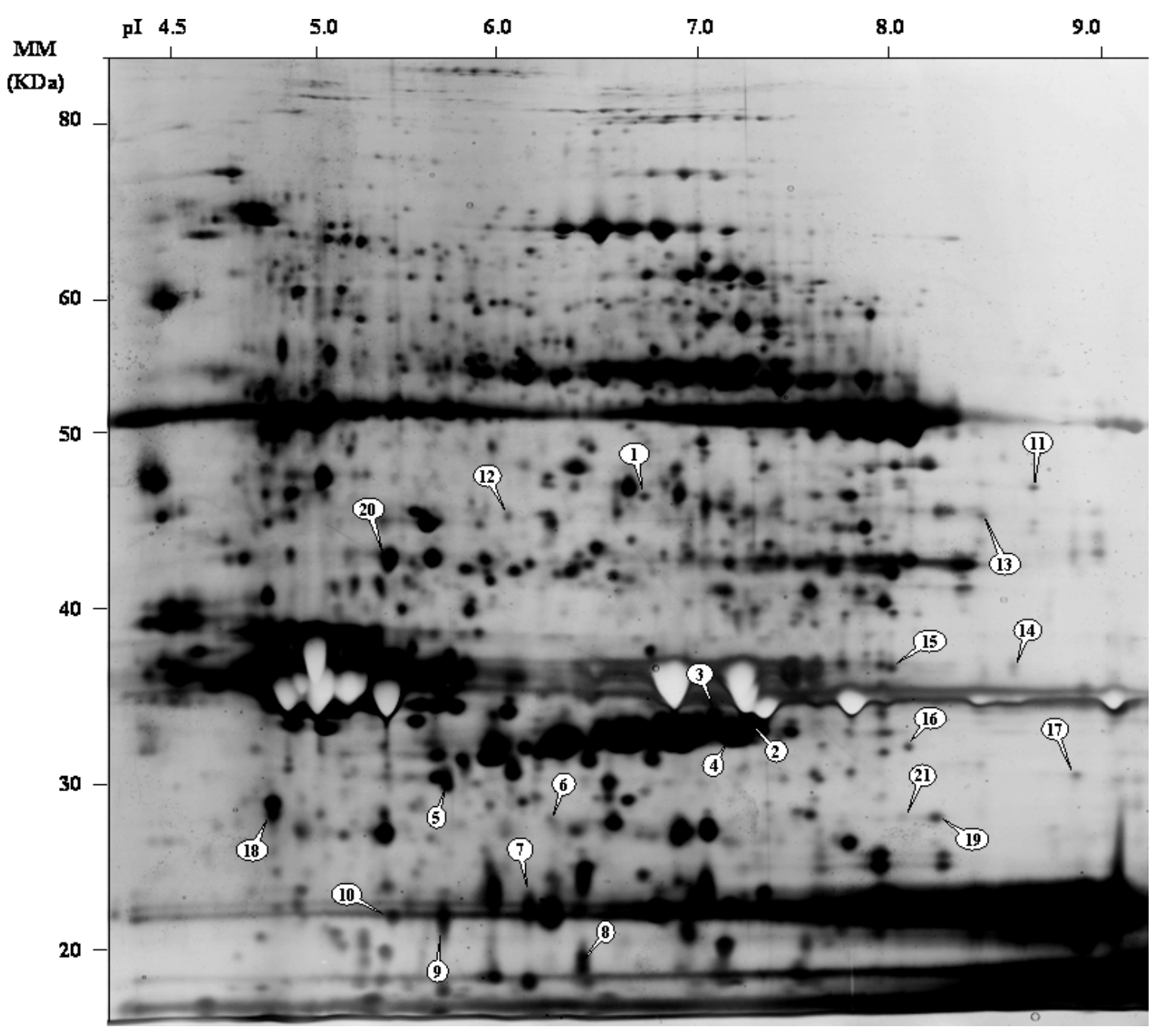

Figure 2 - Silver stained two-dimensional gel of total protein from $M$. ovata seeds. Labelled protein spots presented differential expression during drying and after drying and imbibition.

Protein spots were sorted in three groups, based on the profile of expression after drying or after imbibition, when there was no significant change in the expression after drying. In the first group (Fig.3), protein abundance after desiccation was reduced. On the other hand, proteins from group two (Fig.4) showed higher expression after desiccation of fresh seeds. The third group (Fig.5) contained proteins showing lower expression after drying fresh seeds to $0.25 \mathrm{~g} \mathrm{H}_{2} \mathrm{O} \cdot \mathrm{g}^{-1} \mathrm{dw}$ and subsequently higher expression if the seeds were dried to a low water content $\left(0.10 \mathrm{~g} \mathrm{H}_{2} \mathrm{O} \cdot \mathrm{g}^{-1} \mathrm{dw}\right)$. In general, for all the three groups, the responses were similar for both dried seeds and during subsequent imbibition. However, this was not true for all the spots as seen in Fig.4 (protein spot number 8 ) and Fig.5 (protein spots number 12, 15,
16, 1819 and 21). In the case of spots 8,18 and 21 , after imbibition, a mirrored image of protein expression could be noticed compared to the unimbibed state.

The proteins from group 1 (Fig.3) showed a decrease in abundance after drying fresh seeds.

Down-regulated expression in a set of genes related to maturation was also observed when the drying maturation phase started in Medicago truncatula seeds (Gallardo et al., 2003). Some genes with high expression during the maturation of Brassica oleracea seeds are a sub-group of lateembryogenesis abundant and storage proteins (Soeda et al., 2005).

In spite of the exact function of several downregulated genes being unknown, the logical presumption is that some genes are down- 
regulated because of the fact that their product might not be suited to the new physiological condition caused by dehydration stress (Ramanjulu and Bartels, 2002). Studies have revealed that the transcripts encoding proteins relevant to photosynthesis in Craterostigma plantagineum are down-regulated and have been estimated to represent $36 \%$ of the total number of genes altered during the dehydration process (Bockel et al., 1998).

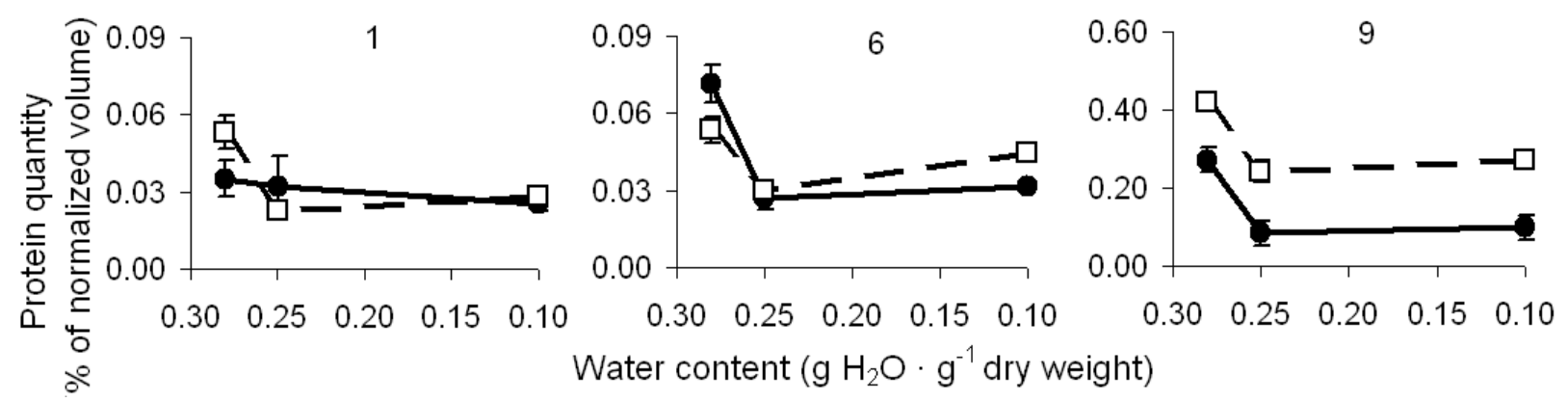

Figure 3 - Expression profiles of proteins from 2D-gels of $M$. ovata seeds showing lower expression after desiccation (solid lines, closed circles). Dashed lines and open squares represent expression during subsequent imbibition.

Group 2 proteins (Fig.4) showed an increase in the abundance after drying of the seeds. This pattern of expression coincided with the stress tolerance. After the imbibition of fresh and dried seeds, spots number 2, 3 and 4 from group 2 showed the same expression pattern as in the dry state (Fig.4), albeit lower. It seemed that these proteins that were induced during desiccation were reduced during subsequent imbibition. It is known that with the initiation of drying, there is a shift in gene expression compelling the seeds to a different physiological status, where genes coding for the protective molecules play an important role (Ramanjulu and Bartels, 2002). Proteins related to desiccation tolerance and involved in the metabolic changes (Leprince et al., 2000; Avelange-Macherel et al., 2006), protection against oxidation and other putative protective molecules show a particular abundance during the desiccation (Pukacka and Ratajczak, 2005). Small heat-shock proteins (sHSPs) (Wehmeyer and Vierling, 2000) and late embryogenesis abundant (LEA) proteins (Gallardo et al., 2001; Boudet et al., 2006) are amongst the molecules with increased the abundance during drying. It is important to notice, however, that the expression of a gene during the water stress alone does not guarantee that the seed becomes able to survive the desiccation (Bray, 1993; Collada et al., 1997).

On the other hand, many other genes show a different pattern of expression during the germination, with a decrease in abundance after the imbibition. Dehydrins, proteins from the group of Lea proteins, are reported to have decreased expression at the start of germination (Roberts et al., 1993; Close, 1997; Buitink, et al. 2003; Boudet, et al. 2006). Some others proteins with high expression in the dry state but decreased abundance during the germination are oleosin, RAB18, EM6, Histone H1and Napin (Soeda et al., 2006) and cytosolic GAPDH (Gallardo et al., 2001).

Protein spots number 5 and 10 showed a significant up regulation $(\mathrm{P}<0.05)$ after the imbibition, but only for the seeds that were dried to the lower water content. After analyzing the expression pattern of these two proteins, it was possible to suggest their participation in a protective mechanism 10 days after the rehydration of the dried seeds. Some Lea proteins and HSPs may provide this protective function not only in the dry state but also throughout the germination. This pattern was observed by Gallardo et al. (2001) and DeRocher and Vierling (1995) in the seeds of Arabidopsis thaliana and Pisum sativum, respectively.

Proteins from the group 3 (Fig.5) presented the most intriguing expression pattern that seemed related to final germination of $M$. ovata seeds (Fig.1). These results suggested the regulation of a number of genes when fresh seeds were dried to $0.25 \mathrm{~g} \mathrm{H}_{2} \mathrm{O} \cdot \mathrm{g}^{-1} \mathrm{dw}$, since all the spots from this group were down-regulated when the seeds were mild dried, with the expression being up-regulated 
again with further drying to $0.10 \mathrm{~g} \mathrm{H}_{2} \mathrm{O} \cdot \mathrm{g}^{-1} \mathrm{dw}$. The expression pattern during the progressing desiccation inversely reflected the germination capacity, and indicated that the low abundance of these proteins was somehow associated with the onset of germination. After the imbibition, the expression for some spots were similar compared to only dried seeds (protein spots number 7, 13 and 17), suggesting that these proteins induced during the drying were still present after the imbibition of dried seeds. On the other hand, protein spot number 21 showed an pattern of expression comparing the dried seeds with dried and imbibed seeds, with an increase upon the imbibition of seeds with higher water content and a strong decrease of the seeds with low water content. This showed a transient increase in the expression that only occurred if the seeds were imbibed after the drying to low water content, weakly mimicked if not dried to such low water content.

Of the 13 protein spots submitted for the identification by mass spectrometry, 10 did not match to any sequences in the databases and three matched the same protein, a Magnolia salicifolia legumin precursor (accession no gi-793854). The peptide sequence GLLLPSFDNAPR produced by the MS spectra from protein spots number 2 (Fig.4) and 21 (Fig.5) matched with the N-terminal cupin domain, while the sequences ADVYNPQAGR and EEIAVFAPR from protein spot number 5 (Fig.4) matched with the C-terminal cupin domain and a down-stream region, respectively.

For the protein spot number 2 (pI 6.8, Mw 32.0) an increased abundance was observed, both after drying fresh seeds to $0.25 \mathrm{~g} \mathrm{H}_{2} \mathrm{O} \cdot \mathrm{g}^{-1} \mathrm{dw}$ and subsequent imbibition treatment $(\mathrm{P}<0.05)$. The expression remained at an elevated level after further drying to $0.10 \mathrm{~g} \mathrm{H}_{2} \mathrm{O} \cdot \mathrm{g}^{-1} \mathrm{dw}$ and subsequent imbibition. The protein spot number 5 (pI 5.6, Mw 28.7) showed a decrease in the abundance after the drying treatment while an increase was noticed after the imbibition of seeds dried to a water content of $0.10 \mathrm{~g} \mathrm{H}_{2} \mathrm{O} \cdot \mathrm{g}^{-1} \mathrm{dw}$. On the other hand, protein spot number 21 (pI 7.8, $\mathrm{Mw}$ 29.0) showed a transient decrease in the abundance after the drying to $0.25 \mathrm{~g} \mathrm{H}_{2} \mathrm{O} \cdot \mathrm{g}^{-1} \mathrm{dw}$ and a contrasting expression behaviour after the imbibition of the seeds. The abundance of spot 21 was much lower than that of the spots 2 and 5 . Legumin and vicilin are the two major seed storage proteins accumulated in large quantities during the development of $P$. sativum L. seeds (Chandler et al., 1983). They are encoded by the multi-gene families of at least 40 genes for $P$. sativum (Casey et al., 2001). The transcripts encoding storage proteins are amongst the most abundant in the embryo. Its accumulation is temporally and spatially regulated during seed development (Kroj et al., 2003; AbirachedDarmency et al., 2005).

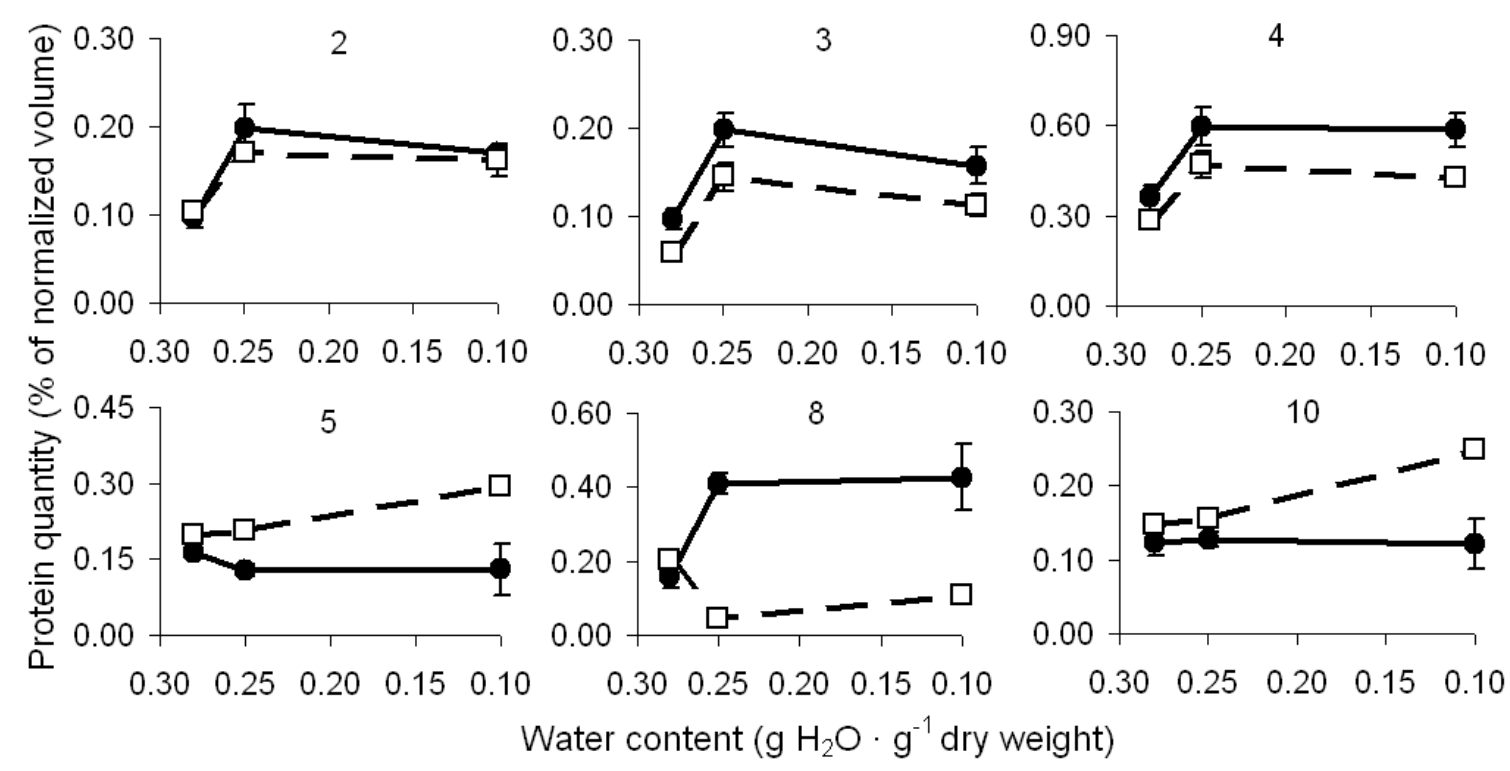

Figure 4 - Expression profiles of proteins from 2D-gels of $M$. ovata seeds showing higher expression after desiccation (solid lines, closed circles). Dashed lines and open squares represent expression during subsequent imbibition. 

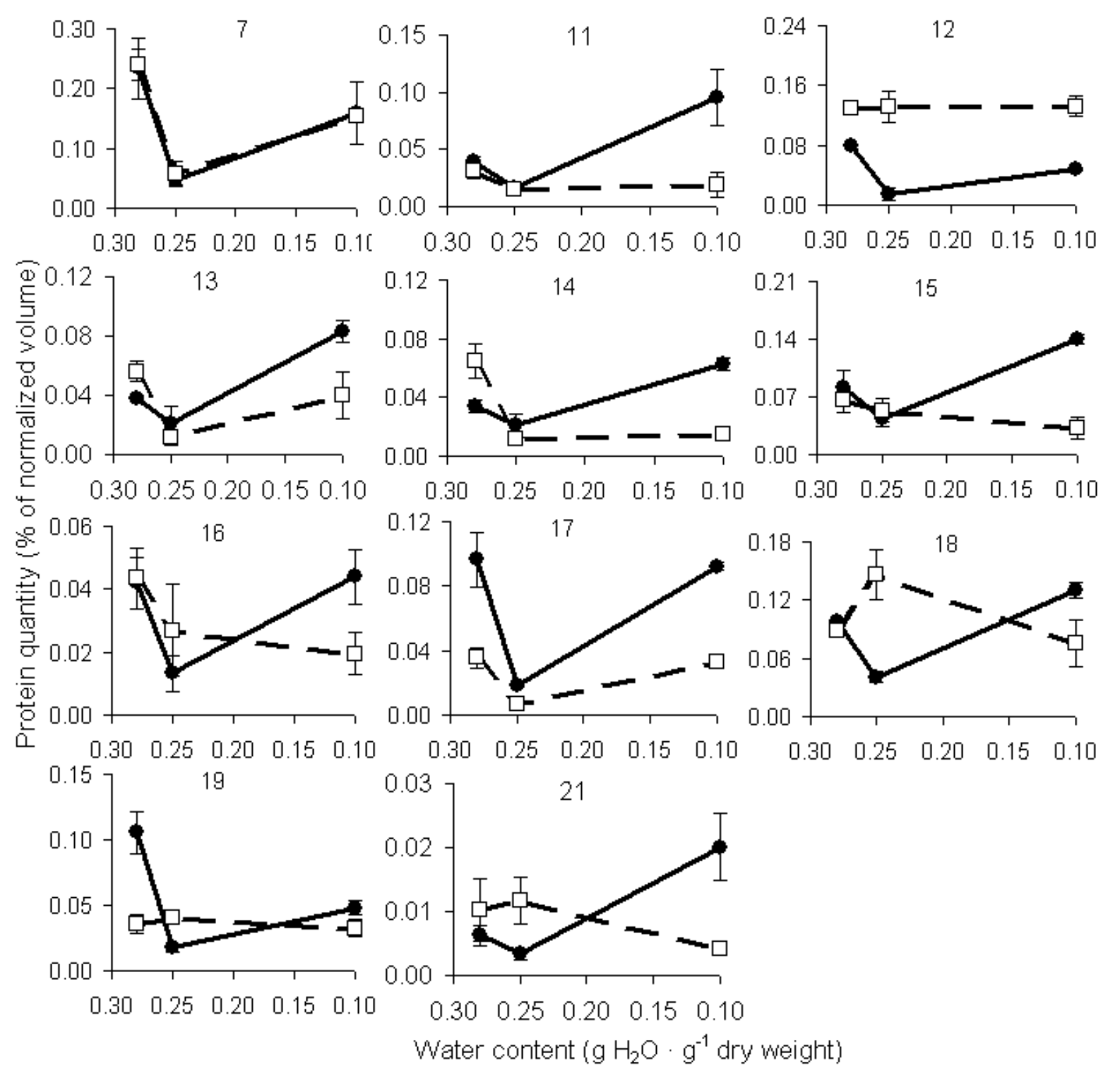

Figure 5 - Expression profiles of proteins from 2D-gels of M. ovata seeds showing transiently lower expression during desiccation (solid lines, closed circles). Dashed lines and open squares represent expression during subsequent imbibition.

In this study, three protein spots matched a legumin precursor from Magnolia salicifolia. This protein is the product of a multi-gene family (Casey et al., 2001), which may explain the presence of more than one spot for the same protein. A multi-gene family consists of group of genes from the same organism that encode the proteins with similar sequences either over their full length or limited to a specific domain.

Sheoran et al. (2005) also identified 11 protein spots in 2-DE gels as legumin-like proteins and
Gallardo et al. (2003) found two spots, identified as precursor forms of legumin, while studying the processes related to reserve accumulation during seed development of $M$. truncatula. Post translational modifications (PTM) could also explain this, since two separate spots (2 and 21) matched with the same oligopeptide sequence. The shift between the spots number 2 and 21 ( $3 \mathrm{kDa}$ and about $1.0 \mathrm{pI}$ unit) might be explained by ubiquitination, which is the modification of a protein by the covalent attachment of one or more 
ubiquitin monomers (a small conserved regulatory protein). It acts as a tag that signals the proteintransport machinery to carry the protein to the proteasome for degradation. This PTM is related to signal destruction (Mann and Jensen, 2003). All the legumin precursor protein spots identified in the 2DE gels presented low expression, which can support the fact of the presence of degradation products.

Another possible explanation for the different expression patterns of the legumin precursor is the regulation of this protein by post-translational modifications (Jung et al., 1997). It is known that during the processing of the mature protein its precursor is cleaved post-translationally and assembled into $11 \mathrm{~S}$ hexamers and then deposited within the specific regions of the inclusion bodies (Stoger et al., 2001).

During the desiccation of fresh seeds transient upregulation of protein expression was observed in the spot number 2 (Fig.3). The opposite expression pattern was found for the protein spot number 21, which could be explained by the post-translational modification of this legumin precursor. These changes were related to differences in the germination (Fig.1), where seeds dried to a water content of $0.18 \mathrm{~g} \mathrm{H}_{2} \mathrm{O} \cdot \mathrm{g}^{-1} \mathrm{dw}$ hadve a higher germination compared to fresh seeds and seeds dried to a water content of $0.10 \mathrm{~g} \mathrm{H}_{2} \mathrm{O} \cdot \mathrm{g}^{-1} \mathrm{dw}$.

There are many reports of increased germination after a mild drying of recalcitrant seeds. This has been attributed to a continuation of the maturation process in recalcitrant seeds during the drying treatment (Pammenter et al., 1998; Faria et al., 2004 and references therein). Indeed, AbirachedDarmency et al. (2005), studying the expression of legumin during the development of M. truncatula and $P$. sativum seeds, suggested the use of legumin A gene as a marker for embryo development. This gene was highly expressed specifically during the embryogenesis (embryo development), similar to the 2-D protein electrophoresis (Gallardo et al. 2003). Boudet et al. (2006) identified a pea $(P$. sativum) legumin precursor homolog in $M$. truncatula radicles associated to desiccation tolerance, but it was attributed to the digestion of storage proteins during germination. The present results suggested the degradation of a legumin during the desiccation that was associated with the germination performance. This would modify the role of legumin as a marker for seed development in M. ovata. A range of other proteins are potential candidates to serve as a seed development marker.

\section{ACKNOWLEDGMENTS}

This work was funded by the Millennium Seed Bank Project, Royal Botanic Gardens, Kew, UK and CAPES, Brazil. We thank the Genetic Heritage Management Council at Brazilian Ministry of the Environment, for allowing for the collection, shipment and access to the genetic heritage of $M$. ovata (application $\mathrm{n}^{\circ}$ 02001.004854/2004-12). We also thank Dr. Sacandé for the determination of oil content, and Drs. Claudette and Dominique Job for the introduction to the fine art of 2-dimensional gel electrophoresis.

\section{REFERENCES}

Abirached-Darmency, M.; Abdel-Gwwad, M. R.; Conejero, G.; Vedeil, J. L. and Thompson, R. (2005), In situ expression of two storage protein genes in relation to histo-differentiation at mid-embryogenesis in Medicago truncatula and Pisum sativum seeds. $J$. Exp. Bot., 56, 2019-2028.

Avelange-Macherel, M-H.; Ly-Vu, B.; Delaunay, J.; Richomme, P. and Leprince, O. (2006), NMR metabolite profiling analysis reveals changes in phospholipid metabolism associated with the reestablishment of desiccation tolerance upon osmotic stress in germinated radicles of cucumber. Plant Cell Environ., 129, 471-482.

Bartels, D. and Salamini, F. (2001), Desiccation tolerance in the resurrection plant Craterostigma plantagineum: a contribution to the study of drought tolerance at the molecular level. Plant Physiol., 127, 1346-1353.

Bertone, P. and Snyder, M. (2005), Prospects and Challenges in Proteomics. Plant Physiol., 138, 560562.

Bockel, C.; Salamini, F. and Bartels, D. (1998), Isolation and characterization of genes expressed during early events of the dehydration process in the resurrection plant Craterostigma plantagineum. J. Plant Physiol., 152, 158-166.

Boudet, J.; Buitink, J.; Hoekstra, F. A.; Rogniaux, H.; Larre, C.; Satour, P. and Leprince, O. (2006), Comparative analysis of the heat stable proteome of radicles of Medicago truncatula seeds during germination identifies late embryogenesis abundant proteins associated with desiccation tolerance. Plant Physiol., 140, 1418-1436.

Bove, J.; Jullien, M. and Grappin, P. (2001), Functional genomics in the study of seed germination. Genome Biol., 3, 1-5. 
Bradford, M. (1976), A rapid and sensitive method for the quantitation of microgram quantities of protein using the principle of protein dye binding. Anal. Biochem., 72, 248-254.

Bray, E. A. (1993), Molecular responses to water deficit. Plant Physiology, 103, 1035-1040.

Buitink, J.; Vu, B. L.; Satour, P. and Leprince, O. (2003), The re-establishment of desiccation tolerance in germinated radicles of Medicago truncatula Gaertn. seeds. Seed Sci. Res., 13, 273-286.

Casey, R.; Christou, P.; Hedley, C.; Hitchin, E.; Parker, M.; Stoger, E.; Wang, T.; Zasiura, C. (2001), Expression of legumin and vicilin genes in pea mutants and the production of legumin in transgenic plants. Nahrung, 45, 385-387.

Cazetta, E.; Rubim, P.; Lunardi, V. O.; Francisco, M. R. and Galetti, M. (2002), Frugivoria e dispersão de sementes de Talauma ovata (Magnoliaceae) no sudeste brasileiro. Ararajuba, 10, 199-206.

Chandler, P.; Higgins, T. J. V.; Randall, P. J. and Spencer, D. (1983), Regulation of legumin levels in developing pea seeds under conditions of sulphur deficiency. Plant Physiol., 71, 47-54.

Close, T. J. (1997), Dehydrin: A commonality in the response of plants to dehydration and low temperature. Physiol. Plantarum, 100, 291-296.

Collada, C.; Casado, L. G. R. and Aragoncillo, C. (1997), Purification and in vitro chaperone activity of a class I small heat-shock protein abundant in recalcitrant chestnut seeds. Plant Physiol., 115, 7177.

DeRocher, A. and Vierling, E. (1995), Cytoplasmatic HSP70 homologues of pea: differential expression in vegetative and embryonic organs. Plant Mol. Biol., 27, 327-335.

Eller, F. J. and King, J.W. (2000), Supercritical carbon dioxide extraction of cedarwood oil: a study of extraction parameters and oil characteristics. Phytochem. Analysis, 11, 226-231.

Ellis, R. H.; Hong, T. D. and Roberts, E.H. (1990), An intermediate category of seed storage behaviour? I. Coffee. J. Exp. Bot., 41, 1167-1174.

Faria, J. M. R.; Van Lammeren A. A. M. and Hilhorst H. W. M. (2004), Desiccation sensitivity and cell cycle aspects in seeds of Inga vera subsp. affinis. Seed Sci. Res., 14, 165-178.

Gallardo, K.; Job, C.; Groot, S. P. C.; Puype, M.; Demol, H.; Vandekerckhove, J. and Job, D. (2001), Proteomic analysis of Arabidopsis seed germination and priming. Plant Physiol., 126, 835-848.

Gallardo, K.; Le Signor, C.; Vandekerckhove, J.; Thompson, R. and Bustin, J. (2003), Proteomics of Medicago truncatula seed development establishes the time frame of diverse metabolic processes related to reserve accumulation. Plant Physiol., 133, 664682.
Gosling, P. G. (2002), Viability testing. In-Seed conservation: turning science into practice, eds. R. D. Smith; J. B. Dickie; S. H. Linington; H. W. Pritchard and R. J. Probert. The Royal Botanic Gardens, London: pp. 445-481.

Hong, T. D.; Linington, S. and Ellis, R. H. (1996), Seed storage behaviour: a compendium. Rome: IPGRI; Rome: Handbooks for Genebanks No. 4. International Pant Genetic Resources Institute.

ISTA. International Seed Testing Association (2005), International rules for seed testing. Seed Sci. Technol., 33, (suppl.).

Jung, R.; Nam, Y-W.; Saalbach, I.; Muntz, K. and Nielsen, N. C. (1997), Role of the sulfhydryl redox state and disulfide bonds in processing and assembly of 11S seed globulins. Plant Cell, 9, 2037-2050.

Koornneef, M.; Bentsink, L. and Hilhorst, H. W. M. (2002), Seed dormancy and germination. Curr. Opin. Plant Biol., 5, 33-36.

Kroj, T.; Savino, G.; Valon, C.; Giraudat, J. and Parcy, F. (2003), Regulation of storage protein gene expression in Arabidopsis. Development, 130, 60656073.

Leprince, O.; Hendry, G. A. F.; Mckersie, B. D. (1993), The mechanisms of desiccation tolerance in developing seeds. Seed Sci. Res., 3, 231-246.

Leprince, O.; Harren, F. J. M.; Buitink, J.; Alberda, M. and Hoekstra, F. A. (2000), Metabolic dysfunction and unabated respiration precede the loss of membrane integrity during dehydration of germinating radicles. Plant Physiol., 122, 597-608.

Mann, M. and Jensen, O. N. (2003), Proteomic analysis of post-translational modifications. Nat. Biotechnol., 21, 255-261.

Morato, G. S.; Calixto, J. B.; Cordeiro, L.; de Lima, T. C. M.; Morato, E. F.; Nicolau, M.; Rae, G. A.; Takahashi, R. N. and Yunes, R. A. (1988), Chemical analysis and pharmacological profile of Talauma ovata (Magnoliaceae). Acta Amaz., 18, 367-380.

Ooi, M. K. J.; Auld, T. D. and Whelan, R. J. (2004), Comparison of the cut and tetrazolium tests for assessing seed viability: a study using Australian native Leucopogon species. Ecol. Man. Rest., 5, 141143.

Pammenter, N. W.; Greggains, V.; Kioko, J. I.; WesleySmith, J.; Berjak, P. and Finch-Savage, W. E. (1998), The time factor during dehydration of non-orthodox (recalcitrant) seeds: effects of differential drying rates on viability retention of Ekebergia capensis. Seed Sci. Res., 8, 463-471.

Pammenter, N. W. and Berjak, P. (1999), A review of recalcitrant seed physiology in relation to desiccationtolerance mechanisms. Seed Sci. Res., 9, 13-37.

Pio-Corrêa, M. (1984), Dicionário das plantas úteis do Brasil e das exóticas cultivadas (vol. 2). Rio de Janeiro: Ministério da Agricultura. 
Pritchard, H. W. (1991), Water potential and embryonic axis viability in recalcitrant seeds of Quercus rubra. Ann. Bot., 67, 43-49.

Probert, R.; Manger, K. R. and Adams, J. (2002), Nondestructive measurement of seed moisture. In- Seed conservation: turning science into practice, eds. R. D. Smith; J. B. Dickie; S. H. Linington; H. W. Pritchard and R. J. Probert. The Royal Botanic Gardens, London: pp. 367-387.

Pukacka, S. and Ratajczak, E. (2005), Production and scavenging of reactive oxygen species in Fagus sylvatica seeds during storage at varied temperature and humidity. J. Plant Physiol., 162, 873-885.

Ramanjulu, S. and Bartels, D. (2002), Drought- and desiccation-induced modulation of gene expression in plants. Plant Cell and Environment, 25, 141-151.

Roberts, E. H. (1973), Predicting the storage life of seeds. Seed Sci. Technol., 1, 499-514.

Roberts, J. K.; DeSimone, N. A.; Lingle, W. L. and Dure, L. (1993), Cellular concentrations and uniformity of cell-type accumulation of two Lea proteins in cotton embryos. Plant Cell, 5, 769-780.

Sacandé, M. (2000), Stress, storage and survival of neen seed. $\mathrm{PhD}$ thesis, Wageningen Agricultural University, Wageningen, The Netherlands.

Sheoran, I. S.; Olson, D. J. H.; Ross, A. R. S. and Sawhney, V. K. (2005), Proteome analysis of embryo and endosperm from germinating tomato seeds. Proteomics, 5, 3752-3764.

Soeda, Y.; Konings, M. C. J. M.; Vorst, O.; van Houwelingen, A. M. M. L.; Stoopen, G. M.; Maliepaard, C. A.; Kodde, J.; Bino, R. J.; Groot, S. P. C. and van der Geest, A. (2005), Gene expression programs during Brassica oleracea seed maturation, osmopriming, and germination are indicators of progression of the germination process and the stress tolerance level. Plant Physiol., 137, 354-368.
Stoger, E.; Parker, M.; Christou, P. and Casey, R. (2001), Pea legumin overexpressed in wheat endosperm assembles into an ordered paracrystalline matrix1. Plant Physiol., 125, 1732-1742.

Sun, W. Q. (2002), Methods for the study of water relations under desiccation stress. In-Desiccation and survival in plants: drying without dying, eds. M. Black and H. Pritchard. CABI Publishing, Wallingford, pp. 47-91.

Sun, W. Q. and Liang, Y. (2001), Discrete levels of desiccation sensitivity in various seeds as determined by the equilibrium dehydration method. Seed Science Research, 11, 317-323.

Van der Geest, A. H. M. (2002), Seed genomics: germinating opportunities. Seed Sci. Res., 12, 145153.

Vertucci, C. W. and Farrant, J. M. (1995), Acquisition and loss of desiccation tolerance. In-Seed development and germination, eds. J. Kigel and G. Galili. Marcel Dekker, Inc, New York, pp. 237-271.

Wehmeyer, N. and Vierling, E. (2005), The expression of small heat shock proteins in seeds responds to discrete developmental signals and suggests a general protective role in desiccation tolerance. Plant Physiol., 122, 1099-1108.

Wood, C. B.; Pritchard, H. W. and Amritphale, D. (2000), Desiccation-induced dormancy in papaya seeds is alleviated by heat shock. Seed Sci. Res., 10, $135-145$.

Received: November 18, 2009; Revised: November 26, 2010; Accepted: March 22, 2011. 